\title{
166
}

\section{Seasonal variation of organic compounds in a eutrophic oxbow lake}

\author{
I. Grigorszky, G. Borics, K. T. Kiss, Cs. Schnitchen, V. Béres, M. Gligora, \\ J. Padisák, Gy. Borbely
}

\section{Introduction}

In many lakes, high planktonic biomass generates such large quantities that bottom waters become anoxic (BARANOVIC et al. 1993, BÁRDOSI et al. 2000, DÉvaI et al. 2002, PADISÁK et al. 2003), and massive organic-mineral aggregates occur in the water column, depending on meteorological and biochemical conditions in the water column (STACHOWITSCH et al. 1990; DegobBis et al. 1995). Chemical and physical speciation of dissolved organic carbon (DOC) impact the formation of aggregates in marine environment, but few studies have addressed the speciation of DOC in lacustrine ecosystems (V-BALOGH et al. 2003). This study reports seasonal variability of DOC, total dissolved carbohydrates (TDCHO), total dissolved free amino acids (TDFAA), and colloidal organic carbon $(\mathrm{COC}>1 \mathrm{kDa})$ in a eutrophic oxbow lake.

Key words: dissolved organic matter; carbohydrates; amino acids;

\section{Materials and methods}

The investigations were made in a small $\left(A_{0}=5\right.$ ha, $\mathrm{d}_{\mathrm{max}}=3.5 \mathrm{~m}, \mathrm{~d}_{\mathrm{avg}}=2 \mathrm{~m}$ ) oxbow at Endröd-KözépsôHolt Körös, Körös area, Békés county, in southeast Hungary ( $\mathrm{N} \mathrm{46} 6^{\circ} 7^{\prime} 14.96^{\prime \prime}$, E $2^{\circ} 49^{\prime} 18.63^{\prime \prime}$ ). Between June 2002 and June 2003, water samples were collected biweekly. Phytoplankton samples were preserved with Lugol's solution in the field. Biomass was estimated by cell volume. The concentration of chlorophyll- $a$ (Chl- $a$ ) was measured according to standard methods (APHA 1989). DOC of Millipore $/ 0.22$ filtered water was assayed by high temperature catalytic oxidation with Shimadzu TOC-5000A analyser. The concentration of carbon was determined against potassium hydrogen phthalate standards and corrected for total blank (ion-exchanged water). TDCHO, including mono-, oligo- and polysaccharides, were analyzed by the MBTH method
(MOPPER et al. 1992). TDFAA were analysed according to CowIE \& HedGes (1992). Tangential flow ultrafiltration (UF) system (Amicon DC10LA) was applied to investigate the molecular weight distribution of the dissolved organic matter (DOM; Guo \& SANTSCHI 1996).

\section{Results and discussion}

TDCHO concentrations were strongly related to DOC (Fig. 1, 2.). TDCHO accounted for $15-20 \%$ of total DOC on average, while TDFAA accounted for about $1 \%$ of DOC (Fig. 3 ). A large fraction $(60-65 \%)$ of the total DOC pool was colloidal, while truly dissolved compounds $(<1 \mathrm{kDa})$ accounted approximately for $35-40 \%$ of the total DOC (Fig. 4). DOC and TDCHO concentrations were higher in summer than winter (Fig. 1, 2, 3). Seasonal changes in the concentration of DOM and Chl- $a$ of particulate matter indicated that phytoplanktonic or-

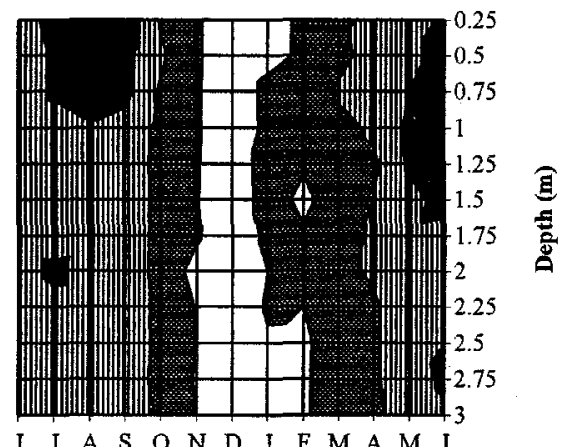

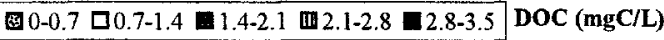

Fig. 1. Seasonal changes of DOC in the studied oxbow lake. 


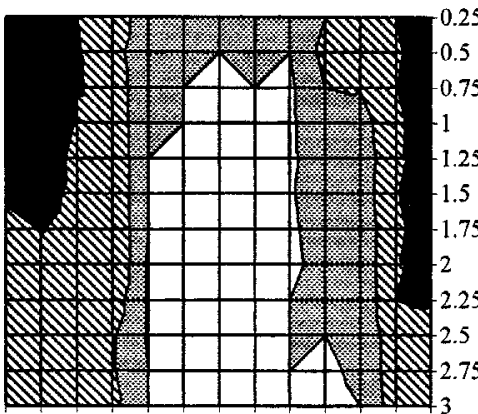

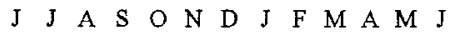

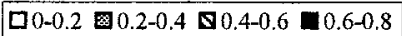

Fig. 2. Seasonal changes of dissolved carbohydrate carbon in studied oxbow.

ganic matter impact the concentration of DOC. Excreted organic materials during the photosynthesis processes of algae was another source of DOM.
The accumulation of dissolved organic matter in summer presumably involves an enrichment in biorefractory compounds discharged by agriculture area around the oxbow lake and an inability of bacteria/Cyanobacteria/algae to consume all the DOC produced. Increases in biological productivity and freshwater residence time, and strong water stratification favoured the accumulation of DOM.

DOM is the main fraction $(80-90 \%)$ of total organic matter in marine environments (KEP$\mathrm{KAY}$ 1994) and is involved in the functioning of the ecosystem. The data set provided on TD$\mathrm{CHO}$ is, to the best of our knowledge, the first available for a eutrophic freshwater ecosystem. In this study the carbohydrates accounted for $20-30 \%$ of DOC and were important constituents of DOM. In summer, concentrations of DOC and TDCHO were found to be higher in surface than bottom waters, while DFAA did not show any significant variation in the water columns. In winter, all the investigated vari-
Fig. 3. Seasonal changes of DOC, dissolved carbohydrate carbon (TDCHO) and total dissolved free aminoacid carbon (TDFAA) at $0.5 \mathrm{~m}$ in studied oxbow.
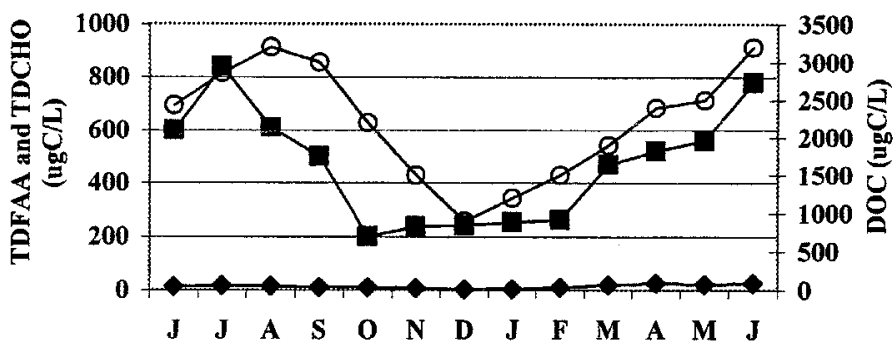

- Total dissolved free aminoacid carbon

-Total dissolved carbohydrate carbon $\multimap$ DOC

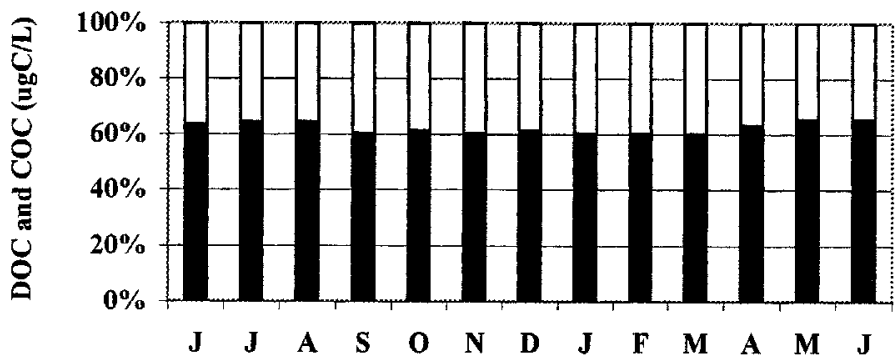

Fig.4. Seasonal changes of dissolved organic carbon (DOC) and colloidal carbon (COC) at $0.5 \mathrm{~m}$ in studied oxbow.

\section{$\square$ Dissolved organic carbon}

Colloidal organic carbon 


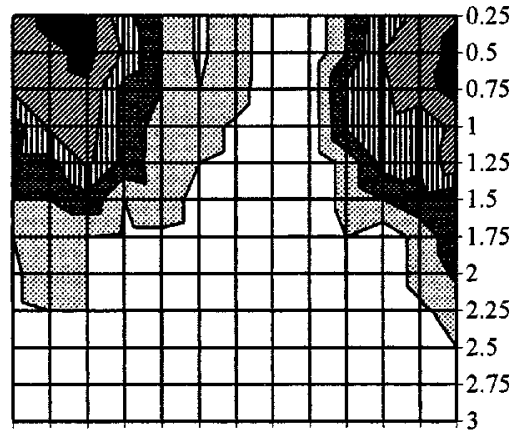

\begin{tabular}{lllllllllllll}
\hline & $J$ & $A$ & $S$ & $O$ & $N$ & $D$ & $J$ & $F$ & $M$ & $A$ & $M$ & $J$
\end{tabular}

\section{References}

APHA, 1989: Standard Methods for the Examination of Water and Wastewaters. - Washington, D.C., USA.

AMON, R.M.W. \& BENNER, R., 1996: Bacterial utilization of different size classes of dissolved organic matter. - Limnol. Oceanogr. 41: 41-51.

Baranovic, A., Solic, M., Vucetic, T. \& Krstulovic, N., 1993: Temporal fluctuations of zooplankton and bacteria in the middle Adriatic Sea. - Mar. Ecol. Prog. Series 92: 65-75.

BÁrdosi, E., NAGY, S., Déval, G.Y., GrigorszKY, I., KISS, B., VÉGVÁRI, P. \& BANCSI, I., 2000: Diversity of oxygen conditions in different backwaters - Hidrol. Közl. 80: 275-278.

COWIE, G.L. \& HEDGES, J.I., 1992: Improved amino acid quantification in environmental samples: charge matched recovery standards and reduced analysis time. - Mar, Chem. 37: 223-238.

Degobbis, D., Fonda-Umani, S., Franco, P., Malej, A., Precali, R. \& SMOdLAKA, N., 1995: Changes in the northern Adriatic ecosystem and the hypertrophic appearance of gelatinous aggregates. - Sci. Tot. Environ. 165: $43-58$.

DÉval, G.Y., NAGY, S.A., CSABAI, Z., Ebesfalvi, S., Kiss, B., LuKács, B.A., MiskolCZI, M., Müller, Z. \& NÉMECZKY, M., 2002: State assessment of the backwater Hordódi-Holt-Tisza based on vegetation surveys and studies of the oxygen budget - Hidrol. Közl. 83: 38-41.

GuO, L., \& SANTSCH, P.H., 1996: A critical evaluation of the cross-flow ultrafiltration technique for sampling colloidal organic carbon in seawater. - Mar. Chem. 55: 113-127.

KEPKAY, P.E., 1994: Particle aggregation and the biological reactivity of colloids. - Mar. Ecol. Prog. Ser. 109: 293-304.

Mopper, K., Schultz, C.A., Chevolot, L., Germain, C., Revuelta, R. \& Dawson, R., 1992: Determination of sugars in unconcentrated seawater and other natural waters by liquid chromatography and pulsed amperometric detection. - Environ. Sci. Technol. 26: 133-138.

PAdisÁ, J., Borics, G., FeHÉr, G., GrigorszKY, I., Oldal, I., SCHMIDT, A. \& ZÁMBÓNÉ-D., ZS., 2003: Dominant species, functional assemblages and frequency of equilibrum phases in late summer phytoplankton assemblages in Hungarian small shallow lakes. - Hydrobiologia. 502: 157-168.

RIEBESELL, U., 1992: The formation of large marine snow and its sustained residence in surface waters. Limnol. Oceanogr. 37: 63-76.

StachowitsCh, M., FAnUKo, N. \& Ritcher, M., 1990: Mucus aggregates in the Adriatic sea: an overview of stages and occurrences. - Mar. Ecol. 11: 327--350.

V-BALOGH, K., Vörös, L., TóTH, N. \& BOKRos, M., 2003: Changes of organic matter quality along the longitudinal axis of a large shallow lake (Lake Balaton). - Hydrobiologia 506-509: 67-74. 
Authors' addresses:

I. GRIGORSZKY, (corresp. author), V. BERES, GY. BORBELY, University of Debrecen, Department of Botany, H-4010 Debrecen, P.O. Box 14, Hungary, E-mail: gege@tigris.klte.hu

G. BoRICs, Transtisanian Inspectorate of Environmental Ministry, H-4032, Debrecen, Piac 9/B, Hungary.

K.T. KIss, Danube Research Station of Hungarian Academic Science, H-2131 Göd, Jávorka S. u. 14, Hungary.
Cs. SCHNITCHEN, University of Debrecen, Department of Ecology, H-4010 Debrecen, P.O. Box 71, Hungary. M. Gligora, University of Zagreb, Faculty of Science, Division of Biology, Roosevetov trg 6, HR-1000 Zagreb, Croatia.

J. PADISÁ, University of Veszprem, Department of Limnology, H-8200 Veszprém, P.O. Box 158, Hungary. 